\title{
Sarcocystidae in wild birds of southeastern Brazil
}

\author{
Sarcocystidae em aves silvestres do sudeste do Brasil \\ Wagner Martins Fontes do Rêgo ${ }^{1}$ (D); Júlia Gatti Ladeia Costa (D); Ramon Castro de Araujo Baraviera (D); \\ Lorena Velozo Pinto' (D); Gabriella de Lima Bessa1 (D); Rosálida Estevam Nazar Lopes (1); \\ Julia Angelica Gonçalves da Silveira¹ (D); Ricardo Wagner Almeida Vitor ${ }^{1 *}$ (1)
}

${ }^{1}$ Departamento de Parasitologia, Instituto de Ciências Biológicas, Universidade Federal de Minas Gerais - UFMG, Belo Horizonte, MG, Brasil

How to cite: Rêgo WMF, Costa JGL, Baraviera RCA, Pinto LV, Bessa GL, Lopes REN, et al. Sarcocystidae in wild birds of southeastern Brazil. Braz J Vet Parasitol 2021; 30(1): e028520. https://doi.org/10.1590/S1984-296120201094

\begin{abstract}
This study aimed to identify members of the Sarcocystidae family in naturally infected wild birds at a rescue center in the state of Minas Gerais, southeastern Brazil. The heart and brain of 44 wild birds were evaluated by bioassay in mice to detect $T$. gondii, and extracted DNA was used for nested PCR of the $18 \mathrm{~S}$ ribosomal DNA gene to detect members of the Sarcocystidae family. The positive samples were sequenced, assembled, edited and compared with sequences deposited in GenBank. Toxoplasma gondii was isolated from six (13.6\%) out of 44 birds. Toxoplasma gondii DNA was identified in 10/44 (22.7\%) of the birds. The amplified sequences exhibited $100 \%$ similarity with the DNA of the ME49 strain of T. gondii. Sarcocystis DNA (99\% similarity) was identified in 5/44 (11.4\%) of the birds. T. gondii and Sarcocystis spp. are common in wild birds in Minas Gerais, Brazil.
\end{abstract}

Keywords: Toxoplasma gondii, Sarcocystis spp., nested PCR, wild birds, Brazil.

\section{Resumo}

O objetivo deste estudo foi identificar membros da família Sarcocystidae em aves silvestres de vida livre naturalmente infectadas e resgatadas no estado de Minas Gerais, Brasil. Coração e cérebro de 44 aves silvestres foram avaliados por bioensaio em camundongos para detecção de T. gondii e extração de DNA para Nested-PCR do gene 185 do DNA ribossomal de membros da família Sarcocystidae. As amostras positivas foram sequenciadas, analisadas, editadas e comparadas com sequências depositadas no GenBank. Toxoplasma gondii foi isolado de seis $(13,6 \%)$ das 44 aves. DNA de T. gondii foi identificado em 10/44 (22,7\%) das 44 aves. As sequências amplificadas exibiram 100\% de similaridade com o DNA da cepa ME49 de T. gondii. DNA de Sarcocystis (99\% de similaridade) foi identificado em 5/44 (11,4\%) das 44 aves. T. gondii e Sarcocystis spp. são encontrados, comumente, em aves silvestres no estado de Minas Gerais, Brasil.

Palavras-chave: Toxoplasma gondii, Sarcocystis spp., nested PCR, aves silvestres, Brasil. 


\section{Introduction}

Parasites of the family Sarcocystidae (Apicomplexa) are associated with a variety of diseases in humans and other animals (Yang et al., 2001). The member genera of the family Sarcocystidae infecting birds are Sarcocystis, Cystoisospora, Toxoplasma, and Frenkelia (Ogedengbe et al., 2016). In addition to these genera, Atoxoplasma spp., causing a disease known as systemic isosporosis, is a coccidian that can infect several species of birds (Mohr et al., 2017).

The genus Sarcocystis comprises approximately 200 species, which vary in their life cycles, pathogenicity and capacities to infect humans, other mammals, birds, reptiles and fish (Odening, 1998). Wild birds can act as definitive and/or intermediate hosts of several species of Sarcocystis (Kutkiene \& Sruoga, 2004). Among the species affecting birds are Sarcocystis horvathi, S. wenzeli, S. rileyi, S. lindsayi, and S. falcatula (Olias et al., 2010). The main factors that hinder the identification and characterization of Sarcocystis species are molecular and morphological similarity (Yang et al., 2001).

Toxoplasma gondii has been identified in wild birds by both bioassay and PCR (Lukášová et al., 2018; Karakavuk et al., 2018). Raptorial birds can become infected by feeding on other intermediate hosts, such as small rodents (Karakavuk et al., 2018), completing the life cycle of $T$. gondii. Non-raptorial birds can become infected by ingesting oocysts via contaminated water or soil (Lindsay et al., 2003).

This study aimed to identify members of the Sarcocystidae family in the heart and brain of naturally infected wild birds rescued in the state of Minas Gerais, southeastern Brazil.

\section{Material and Methods}

The study protocol was approved by the Ethics Committee in Animal Experimentation (CETEA) of the Universidade Federal de Minas Gerais, Brazil (Protocol CEUA 67/2016). Procedures for the collection, transport, and manipulation of free-living wild birds were authorized by the Biodiversity Authorization and Information System of the Federal Government, Brazil (SISBIO no. 52653-1).

The hearts and brains of 44 wild birds rescued in the state of Minas Gerais that had been collected on the day of death between August 2016 and June 2017 were used in a bioassay to detect $T$. gondii and subjected to DNA extraction. The organs were collected from the rescued birds after natural death at the Centro de Triagem de Animais Silvestres (CETAS; Belo Horizonte, Minas Gerais state), which is associated with the Instituto Brasileiro do Meio Ambiente e dos Recursos Naturais Renováveis (IBAMA). Birds evaluated in this study were: Amazona aestiva* (1 individual), Ardea alba (1), Aramides saracura (1), Asio clamator (4), Asio stygius (1), Athene cunicularia (3), Caracara plancus (7), Cariana cristata (1), Colaptes campestris* (1), Coragyps atratus (2), Falco sparverius (2), Geranoaetus albicaudatus (1), Glaucidium brasilianum (2), Megascops choliba (3), Milvago chimachima (2), Patagioenas speciosa* (1), Pionus maximiliani* (1), Ramphastos toco (3), Rupornis magnirostris (7). Of the birds, 40 were raptorial, and four (marked by an asterisk) were non-raptorial species.

Half of the heart and half of the brain from each of the 44 birds were cut into small pieces and digested according to Dubey et al. (2004). Digested tissue was inoculated into four Swiss female mice obtained from a Toxoplasma gondii free colony at the Federal University of Minas Gerais (CEBIO, UFMG). Two mice were inoculated with digested heart tissue, and the other two were inoculated with digested brain tissue by the subcutaneous via. Mice were provided water and food ad libitum and maintained under a $12 \mathrm{~h}$ light/12 $\mathrm{h}$ dark light cycle. A technician with specialized training monitored animal health and behavior twice a day for 45 days post infection (d.p.i.). All efforts were made to minimize animal suffering during the course of this study. Moribund and surviving mice (after 45 d.p.i.) were euthanized by an intraperitoneal (i.p.) overdose of ketamine (300 mg/kg) and xylazine (45 mg/kg). Mice were examined for the presence of tachyzoites in the lung and brain cysts. At 45 d.p.i., each surviving mouse was bled by lancing the tail, and blood was collected for an in-house ELISA according to Brandão et al. (2009). Only the brains of seropositive mice were removed for analysis of brain cysts. A bioassay result was considered positive when tachyzoites and/or cysts were detected in the inoculated mouse.

The remaining halves of the hearts and brains from the 44 birds were macerated individually and DNA was extracted using the Wizard Genomic Purification Kit (Promega, Cat. A1120) with modifications proposed by Cunha et al. (2016). When half of the organ weighed more than $20 \mathrm{mg}$ (maximum weight recommended by the manufacturer in each extraction), two extractions were performed simultaneously. In these cases, the DNA resulting were homogenized in a single sample. The 185 gene of ribosomal DNA of members of the Sarcocystidae family was 
amplified by nested PCR (Vitaliano et al., 2014) using external primers Tg18s48F (5'CCATGCATGTCTAAGTATAAGC3') and Tg18s359R (5'GTTACCCGTCACTGCCAC3'), and internal primers Tg18s58F (5'CTAAGTATAAGCTTTTATACGGC3') and Tg18s348R (5'TGCCACGGTAGTCCAATAC3') (Invitrogen). The DNA extracted from tachyzoites of the RH strain was used as control.

PCR amplification was carried out in a Mastercycler Nexus thermal cycler (Eppendorf) using Invitrogen reagents. The cycling conditions were as follows: initial denaturation at $94{ }^{\circ} \mathrm{C}$ for $2 \mathrm{~min}$; followed by 30 cycles of $94{ }^{\circ} \mathrm{C}$ for $30 \mathrm{~s}$, annealing at $57^{\circ} \mathrm{C}$ and extension at $68^{\circ} \mathrm{C}$ for $30 \mathrm{~s}$; and a final extension step at $68^{\circ} \mathrm{C}$ for 1 min. For nested $\mathrm{PCR}$, the same conditions used for the initial PCR were used except for the use of 35 amplification cycles. To verify the absence of contaminants, a negative control was included.

The PCR products were purified by the addition of an equal volume of polyethylene glycol (PEG) (20\% PEG 8,000 in $2.5 \mathrm{M} \mathrm{NaCl}$ (Promega). After vortex homogenization for $60 \mathrm{~s}$ and incubation in a $37^{\circ} \mathrm{C}$ water bath for $15 \mathrm{~min}$, the products were centrifuged for $15 \mathrm{~min}$ at $15,700 \mathrm{~g}$, and the supernatant was discarded. Each pellet was washed twice with $125 \mu \mathrm{L}$ of chilled $80 \%$ ethanol and then centrifuged for 5 min at 15,700 g. The final pellet was maintained in an oven at $37^{\circ} \mathrm{C}$ until the ethanol had fully evaporated. Then, the DNA was rehydrated with $12 \mu \mathrm{L}$ of ultrapure water for PCR (Phoneutria), quantified with a NanoDrop ND-1000 (Thermo Fisher Scientific) and electrophoresed to confirm the presence of $300 \mathrm{bp}$ product. DNA amplified from each sample was sequenced by Myleus Biotechnology (2020) using the 96-capillary 3730 DNA Analyzer (Thermo Fisher Scientific).

The obtained sequences were assembled and edited with the help of ChromasPro version 2.0.1 (Technelysium Pty Ltd, Australia) to obtain a single consensus sequence. The similarity with sequences deposited in GenBank was analyzed using the Basic Local Alignment Search Tool (BLAST) of the National Center for Biotechnology Information (NCBI, 2020) of the National Library of Medicine, USA.

\section{Results}

During bioassay follow-up, T. gondii was found in 10 moribund mice (signs of disease occurred between 8 and 15 d.p.i.), and in four surviving seropositive mice, in all cases after euthanasia. Overall, viable $T$. gondii parasites were isolated by mouse bioassay in six of the 44 (13.6\%) wild birds assessed in this study. In the six birds yielding positive bioassay results, $T$. gondii was isolated from all of the heart samples but only in 3/6 brain samples (Table 1). Toxoplasma gondii DNA was identified in 10/44 (22.7\%) of the birds. The amplified sequences in all of these samples exhibited $100 \%$ similarity with the DNA of the ME49 strain of T. gondii. Only one (a Colaptes campestris individual) of the 44 wild birds found positive for $T$. gondii via PCR and/or bioassay belonged to a species not considered raptorial (Table 1).

PCR identified Sarcocystis DNA in 5/44 (11.4\%) of the birds. The amplified sequences in all of these samples exhibited $99 \%$ similarity with the DNA of Sarcocystis spp. (Table 1). In 3/44 (6.8\%) of the birds, the amount of amplified DNA was insufficient for sequencing. Overall, Sarcocystidae members ( $T$. gondii and Sarcocystis spp.) were identified in $19(47.5 \%)$ of the 40 raptorial birds and in $25 \%(1 / 4)$ of the non-raptorial birds (Table 1$)$.

\section{Discussion}

The molecular methods (amplification and sequencing of $T$. gondii DNA) proved to be more sensitive in detecting T. gondii than isolation by bioassay in mice. Toxoplasma gondii was isolated from six of the 44 birds. Rêgo et al. (2018) genotyped these isolates and identified five different genotypes by PCR-RFLP. A unique genotype, not previously described was common to two isolates. Genetic sequencing revealed T. gondii DNA in heart and/or brain in 10 wild birds, among which T. gondii was isolated from only four (Ramphastos toco, Colaptes campestris, Megascops choliba and Caracara plancus), all considered raptors, except C. campestris. On the other hand, T. gondii DNA was not amplified in two birds (Rupornis magnirostris and C. plancus) from which the parasite was isolated. These results were probably due to an uneven distribution of $T$. gondii in tissue samples of the birds, as previously observed in muscles of naturally infected domestic animals (Rani et al., 2020). The grinding of the whole organ, followed by the separation of two portions for the experiments (bioassay and PCR) could result in greater agreement between the two tests used in the present study. Our results are consistent with those of Vitaliano et al. (2014), who found a higher sensitivity of molecular methods than bioassay when analyzing 226 heart and brain samples from wild animals (with 28 samples found positive by PCR and only 15 samples found positive by bioassay). 


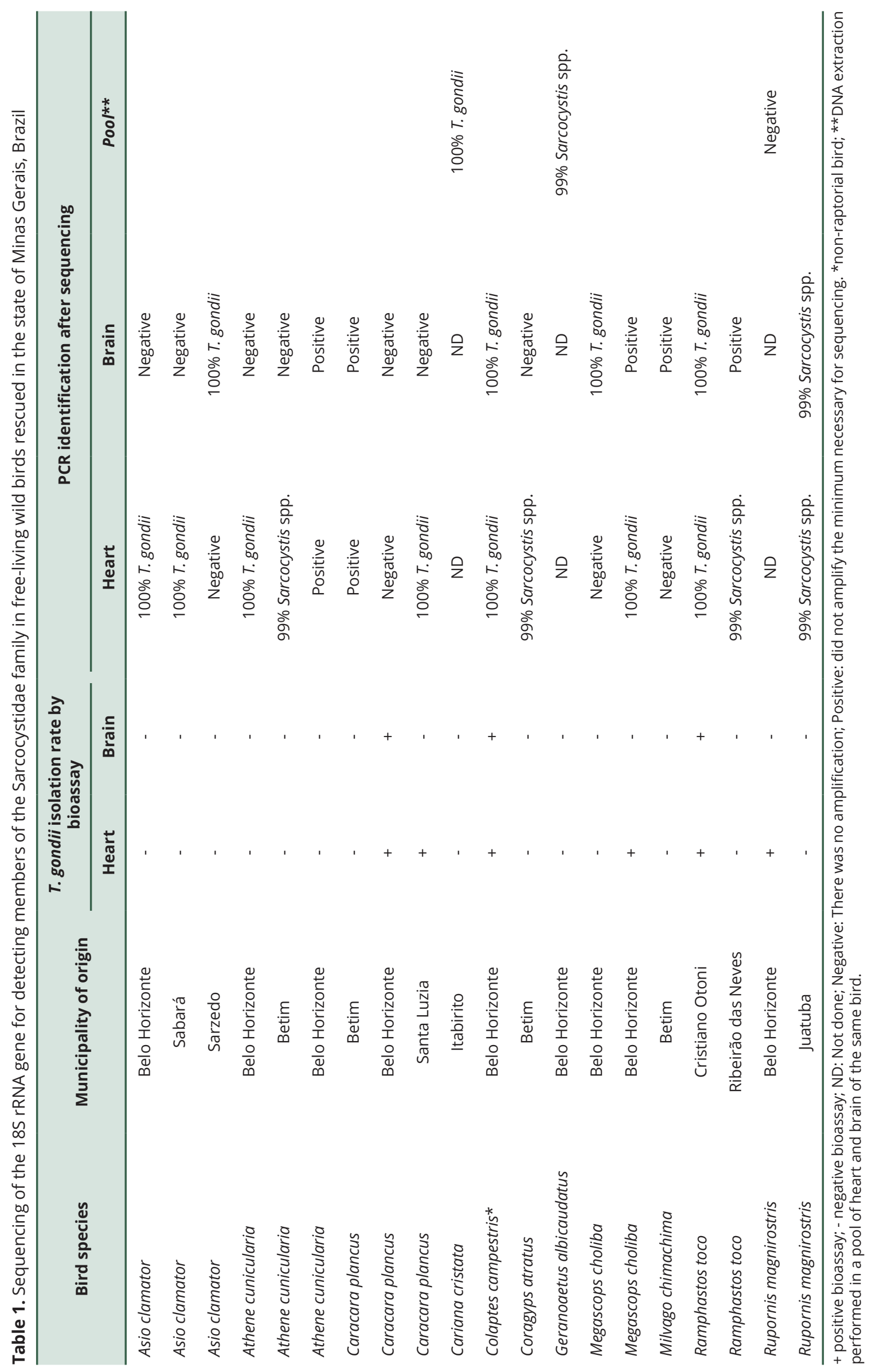


Based on the organ distribution of T. gondii in wild birds in this study, the heart seems to be more frequently parasitized than the brain, by bioassay or by PCR. Our results corroborate observations in South Africa, where a low occurrence $(2.7 \% ; 3 / 110)$ of T. gondii in the brain of wild birds was identified (Lukášová et al., 2018). However, in naturally infected free-range chickens in Brazil, no trend of greater parasitism in heart or brain was observed (Ferreira et al., 2018).

Few studies have been conducted to identify birds as potential hosts of Sarcocystis. Twelve species of this genus use birds as definitive hosts, and another 22 use them as intermediate hosts. Two additional species can use birds as final and intermediate hosts (Odening, 1998). In this work, we verified that wild birds rescued in the state of Minas Gerais were infected with members of the genus Sarcocystis. However, it was not possible to identify these parasites to the species level in all cases. Recent studies have identified species of Sarcocystis in wild birds and have characterized clinical aspects of infection. Gjerde et al. (2017) identified the simultaneous presence of three species of Sarcocystis (S. halieti, S. lari and S. truncata) in a Haliaeetus albicilla individual rescued in Western Norway. The DNA of these three species was identified in segments of intestinal mucosa containing sporulated oocysts of Sarcocystis via PCR amplification and sequencing of four regions: the $18 \mathrm{~S}$ and $28 \mathrm{~S}$ rRNA genes, the ITS1 region and the cox1 gene. Konradt et al. (2017) described pathological and molecular findings of Sarcocystis infection in Phimosus infuscatus, which caused necrotizing meningoencephalitis, in southern Brazil. They found that the gene encoding ITS1 in schizonts of the studied Sarcocystis sp. had 100\% similarity with homologous sequence in Sarcocystis sp. which infects Didelphis albiventris in Brazil. Further studies using ITS1, 28S, 18S and cox1 genes (Hoeve-Bakker et al., 2019) should be performed for Sarcocystis species identification in wild birds of southeastern Brazil.

An intrinsic limitation of studies designed to molecular diagnosis based on Nested-PCR is the susceptibility to contaminations. To minimize contaminations, different parts of the method were done in physically separate rooms from one another. Other limitation of the present study was the bird size and consequently the organs size, that restrict sample amount analyzed.

\section{Conclusion}

Compared with isolation by bioassay, the amplification of the $18 \mathrm{~S}$ rDNA gene identified $T$. gondii in a larger number of samples. Members of the family Sarcocystidae are common in wild birds in Minas Gerais, Brazil.

\section{References}

Brandão GP, Melo MN, Gazzinelli RT, Caetano BC, Ferreira AM, Silva LA, et al. Experimental reinfection of BALB/c mice with different recombinant type I/III strains of Toxoplasma gondii: involvement of IFN-y and IL-10. Mem Inst Oswaldo Cruz 2009; 104(2): 241-245. http://dx.doi.org/10.1590/S0074-02762009000200017. PMid:19430649.

Cunha MM, Carneiro ACAV, Costa JGL, Vitor RWA. Genotyping of Toxoplasma gondii directly from human and animal biological samples: from partial genotypes to a new genotype. J Parasitol 2016; 102(1): 157-160. http://dx.doi.org/10.1645/15-813. PMid:26418172.

Dubey JP, Graham DH, Young RW, Dahl E, Eberhard ML, Nace EK, et al. Molecular and biologic characteristics of Toxoplasma gondii isolates from wildlife in the United States. J Parasito/ 2004; 90(1): 67-71. http://dx.doi.org/10.1645/GE-110R. PMid:15040668.

Ferreira TCR, Buery JC, Moreira NIB, Santos CB, Costa JGL, Pinto LV, et al. Toxoplasma gondii: isolation, biological and molecular characterisation of samples from free-range Gallus gallus domesticus from countryside Southeast Brazil. Rev Bras Parasitol Vet 2018; 27(3): 384-389. http://dx.doi.org/10.1590/s1984-296120180028. PMid:29846444.

Gjerde B, Vikoren T, Hamnes IS. Molecular identification of Sarcocystis halieti n. sp., Sarcocystis lari and Sarcocystis truncata in the intestine of a white-tailed sea eagle (Haliaeetus albicilla) in Norway. Int J Parasitol Parasites Wildl 2017; 7(1): 1-11. http://dx.doi. org/10.1016/j.jppaw.2017.12.001. PMid:29270360.

Hoeve-Bakker BJA, van der Giessen JWB, Franssen FFJ. Molecular identification targeting cox1 and 18S genes confirms the high prevalence of Sarcocystis spp. in cattle in the Netherlands. Int J Parasitol 2019; 49(11): 859-866. http://dx.doi.org/10.1016/j. ijpara.2019.05.008. PMid:31400377.

Karakavuk M, Aldemir D, Mercier A, Sahar EA, Can H, Murat JB, et al. Prevalence of toxoplasmosis and genetic characterization of Toxoplasma gondii strains isolated in wild birds of prey and their relation with previously isolated strains from Turkey. PLoS One 2018; 13(4): e0196159. http://dx.doi.org/10.1371/journal.pone.0196159. PMid:29668747.

Konradt G, Bianchi MV, Leite-Filho RV, Silva BZ, Soares RM, Pavarini SP, et al. Necrotizing meningoencephalitis caused by Sarcocystis falcatula in bare-faced ibis (Phimosus infuscatus). Parasitol Res 2017; 116(2): 809-812. http://dx.doi.org/10.1007/s00436-016-53416. PMid:27915419. 
Kutkiene L, Sruoga A. Sarcocystis spp. in birds of the order Anseriformes. Parasitol Res 2004; 92(2): 171-172. http://dx.doi. org/10.1007/s00436-003-1018-z. PMid:14648204.

Lindsay DS, Collins MV, Mitchell SM, Cole RA, Flick GJ, Wetch CN, et al. Sporulation and survival of Toxoplasma gondii oocysts in seawater.J Eukaryot Microbio/ 2003;50(Suppl 1):687-688. http://dx.doi.org/10.1111/j.1550-7408.2003.tb00688.x. PMid:14736220.

Lukášová R, Kobédová K, Halajian A, Bártová E, Murat JB, Rampedi KM, et al. Molecular detection of Toxoplasma gondii and Neospora caninum in birds from South Africa. Acta Trop 2018; 178: 93-96. http://dx.doi.org/10.1016/j.actatropica.2017.10.029. PMid:29092798.

Mohr F, Betson M, Quintard B. Investigation of the presence of Atoxoplasma spp. in blue-crowned laughingthrush (Dryonastes courtoisi) adults and neonates. J Zoo Wildl Med 2017; 48(1): 1-6. http://dx.doi.org/10.1638/2016-0044.1. PMid:28363058.

Myleus Biotechnology [online]. 2020 [cited 2020 Dec 8]. Available from: https://www.myleus.com/

National Center for Biotechnology Information - NCBI [online]. 2020 [cited 2020 Dec 8]. Available from: https://www.ncbi.nlm. nih.gov/

Odening K. The present state of species-systematics in Sarcocystis Lankester, 1882 (Protista, Sporozoa, Coccidia). Syst Parasitol 1998; 41(3): 209-233. http://dx.doi.org/10.1023/A:1006090232343.

Ogedengbe ME, Ogedengbe JD, Whale JC, Elliot K, Juárez-Estrada MA, Barta JR. Molecular phylogenetic analyses of tissue coccidia (sarcocystidae; apicomplexa) based on nuclear 18s RDNA and mitochondrial COI sequences confirms the paraphyly of the genus Hammondia. Parasitol Open 2016; 2: e2. http://dx.doi.org/10.1017/pao.2015.7.

Olias P, Gruber AD, Kohls A, Hafez HM, Heydorn AO, Mehlhorn H, et al. Sarcocystis species lethal for domestic pigeons. Emerg Infect Dis 2010; 16(3): 497-499. http://dx.doi.org/10.3201/eid1603.090860. PMid:20202429.

Rani S, Cerqueira-Cézar CK, Murata FHA, Kwok OCH, Dubey JP, Pradhan AK. Distribution of Toxoplasma gondii tissue cysts in shoulder muscles of naturally infected goats and lambs. J Food Prot 2020; 83(8): 1396-1401. http://dx.doi.org/10.4315/JFP-20024. PMid:32294177.

Rêgo WMF, Costa JGL, Baraviera RCA, Pinto LV, Bessa GL, Lopes REN, et al. Genetic diversity of Toxoplasma gondii isolates obtained from free-living wild birds rescued in Southeastern Brazil. Int J Parasitol Parasites WildI 2018; 7(3): 432-438. http://dx.doi. org/10.1016/j.jppaw.2018.11.001. PMid:30479944.

Vitaliano SN, Soares HS, Minervino AHH, Santos ALQ, Werther K, Marvulo MFV, et al. Genetic characterization of Toxoplasma gondii from brazilian wildlife revealed abundant new genotypes. Int J Parasitol Parasites Wildl 2014; 3(3): 276-283. http://dx.doi. org/10.1016/j.ijppaw.2014.09.003. PMid:25426424.

Yang ZQ, Zuo YX, Ding B, Chen XW, Luo J, Zhang YP. Identification of Sarcocystis hominis-like (Protozoa: Sarcocystidae) cyst in Water Buffalo (Bubalus bubalis) based on 18S rRNA gene sequences. J Parasitol 2001; 87(4): 934-937. http://dx.doi.org/10.1645/00223395(2001)087[0934:IOSHLP]2.0.CO;2. PMid:11534667. 